Jadwiga Serkowska-Mqka ORCID: 0000-0002-9884-6340

Wyższa Szkoła Menedżerska w Warszawie

\title{
Szkoła dla Innego. Filozofia i pedagogika dialogu w edukacii międzykulturowej
}

\author{
A School for the Other: Philosophy of Dialogue \\ and Dialogic Pedagogy in Intercultural Education
}

\begin{abstract}
ABSTRAKT
Celem artykułu jest pokazanie, w jaki sposób funkcjonujaca w ramach pedagogiki dialogu propozycja Joanny Rutkowiak, aby uczynić dialog naczelnq zasadq wychowania, może pomóc w realizacji zadań edukacji międzykulturowej. Szczególnq uwagę autorka zwraca na myślenie globalizujące $\mathrm{i}$ hermeneutycznie rozumianq rozmowę, które moga przyczynić się do poznawczego przeobrażenia jednostki poprzez uwzględnianie i włączanie do swojego horyzontu poznawczego odmiennych punktów widzenia. Takie podejście może przyczynić się do kształtowania sprzyjających wychowaniu międzykulturowemu postaw u nauczycieli, przeobrażając ich nastawienie i zwiększajqc samoświadomość co do własnego światopoglqdu, wartości, przekonań i zachowań. Ta samoświadomość jest kluczowa w środowisku wielokulturowym, gdzie dochodzi do wzmożonych napięć i konfrontacji pomiędzy odmiennymi kulturowo interpretacjami rzeczywistości, wartościami i normami. Autorka twierdzi, że kluczowq rolę w edukacji międzykulturowej odgrywaja nauczyciele, gdyż to od nich zależy skuteczne kształtowanie postaw otwartości i tolerancji
\end{abstract}

StOWA KLUCZOWE edukacja międzykulturowa, wielokulturowość, dialog, pedagogika dialogu, filozofia dialogu, Inny, nauczyciel

\section{KEYWORDS}

intercultural education, multiculturality, dialogue, dialogic pedagogy, philosophy of dialogue, Other, teacher

SPI Vol. 22, 2019/1

ISSN 2450-5358

e-ISSN 2450-5366

DOI: 10.12775/SPI.2019.1.003

Nadesłano: 03.10.2018 Zaakceptowano: 18.03.2019

Artykuły i rozprawy 
wobec Innego u uczniów. Wychowawcy powinni pełnić rolę negocjatorów między różnymi punktami widzenia, łłumaczy odmienności kulturowej oraz propagatorów otwartości i tolerancji. Nie uda się to bez zwiększonej świadomości własnego zaplecza kulturowego i wysokiego poziomu samoświadomości. Pomóc w tym może właśnie perspekływa dialogowa Rutkowiak, połączona z zaczerpnięta z filozofii dialogu dyrektywq zwiększonej wrażliwości na Innego i jego specyficzne potrzeby i uwarunkowania.

\section{ABSTRACT}

The aim of this article is to demonstrate how Joanna Rutkowiak's concept of educational dialogue representing dialogic pedagogy can help in the accomplishment of the goals of intercultural education. The author's attention is focused particularly on globalizing thinking and hermeneutically understood conversation, which can be important factors leading to the cognitive transformation of an individual accomplished by taking different points of view into consideration and including them in one's cognitive horizon. Such an approach may contribute to the development of particular teacher attitudes which support intercultural upbringing. These attitudes can be formed by transforming teachers' dispositions and increasing their self-awareness in areas such as worldview held, beliefs, values and manifested behaviors. This self-awareness is the key factor in a multicultural environment, which is an area of increased tensions and conflicts between culturally different values, norms and interpretations of reality. The author argues that teachers play the key role in intercultural education, because effective fostering of openness and tolerance towards Other depends on their efforts. Educators should play the role of negotiators between differing points of view, translators of cultural otherness and exponents of openness and tolerance. They will not be able to achieve this goal without increased awareness of their cultural background and a high level of self-awareness.

\section{Wstęp}

W Polsce nie istnieje działający na większą skalę model działań międzykulturowych. Powodem takiego stanu rzeczy jest silna homogeniczność kulturowa i etniczna naszego państwa i niewielka liczebność mniejszości narodowych. Jednak sytuacja pod tym względem ulega zmianie w sposób dynamiczny, a działające od jakiegoś 
czasu procesy polityczne i społeczne, takie jak trwająca od 1989 roku demokratyzacja, wstąpienie Polski do Unii Europejskiej oraz do strefy Schengen czy nasilające się m.in.w Europie procesy migracyjne, wymuszą - prędzej czy później - wypracowanie określonych rozwiązań teoretycznych i praktycznych dostosowanych do specyfiki sytuacji w kraju.

Nasz kraj cieszy się rosnącym z roku na rok zainteresowaniem cudzoziemców, chcących przebywać w Polsce czasowo lub na stałe ${ }^{1}$. W 2017 roku o zezwolenia na pobyt ubiegało się 202 tysiące cudzoziemców. To o 33\% więcej niż w 2016 roku i o 71\% więcej niż w 2015 roku. O zezwolenia na pobyt ubiegało się 192 tysiące obcokrajowców z państw trzecich (spoza UE). Pobyt zarejestrowało także 10 tysięcy osób pochodzących z państw Unii Europejskiej. Większość, bo ok. 62\% wszystkich wniosków, złożyli obywatele Ukrainy. Najczęstszym powodem przybycia do Polski jest chęć podjęcia pracy.

Od 2014 roku stale rośnie liczba cudzoziemców ubiegających się o zezwolenia na pobyt w Polsce. Najwięcej jest migracji czasowych w 2017 roku 88\% wniosków dotyczyło zezwoleń na pobyt czasowy (do 3 lat), 10\% - pobytu stałego, a 2\% - pobytu rezydenta długoterminowego UE.

Wśród cudzoziemców chcących zamieszkać w Polsce najwięcej było obywateli Ukrainy, którzy złożyli 125 tysięcy wniosków - o 30\% więcej niż w 2016 roku. Najczęściej o zezwolenia na pobyt ubiegali się także: Białorusini (9,5 tysiąca), Hindusi (8 tysięcy), Wietnamczycy (6,4 tysiąca) oraz Chińczycy (6 tysięcy). Rosnące zainteresowanie legalizacją pobytu można zauważyć zwłaszcza wśród obywateli Białorusi oraz Indii, którzy złożyli odpowiednio o 98 i 95\% więcej wniosków niż w 2016 roku. W przypadku obywateli państw członkowskich UE w 2017 roku pobyt w Polsce zarejestrowało 10 tysięcy cudzoziemców. Najczęściej byli to Niemcy (2,3 tysiąca), Włosi (1,1 tysiąca), Bułgarzy (0,8 tysiąca) oraz obywatele Rumunii i Wielkiej Brytanii (po 0,7 tysiąca).

1 Dane statystyczne w tym i kolejnych paragrafach pochodzą z: Urząd do Spraw Cudzoziemców, https://udsc.gov.p1/statystyki/raporty-okresowe/raportroczny-legalizacja-pobytu/2017-2/ [dostęp: 29.08.2018]. 


\section{Edukacja międzykulturowa i jej cele}

Wiele wskazuje na to, że wyłaniające się z tych statystyk trendy wzrostu liczby imigrantów w Polsce będą się utrzymywać i sprawią, że kwestią coraz większej wagi stanie się w naszym kraju edukacja wielo- i międzykulturowa. Edukacja międzykulturowa różni się od wielokulturowej tym, że ta druga nastawiona jest raczej na zachowanie, ochronę i rozwijanie różnych kultur istniejących obok siebie na określonym terytorium i ewentualnego poznawania kultur obcych, natomiast w wypadku tej pierwszej chodzi o otwarcie się na inność kulturową, wzajemną współpracę, wspieranie się, uczenie się od siebie i o sobie oraz szukanie porozumienia ${ }^{2}$. Mamy zatem do czynienia w wypadku edukacji międzykulturowej z silnym podkreśleniem elementu interakcji, przejmowania wartościowych elementów innych kultur nieobecnych w naszej społeczności, dzielenia się własnymi cennymi wartościami. Jak zauważa Jerzy Nikitorowicz: „wielokulturowość jest faktem, a międzykulturowość zadaniem i wyzwaniem edukacyjnym"3.

W grę wchodzi przy tym przeobrażanie się kultur pod wpływem kontaktu $\mathrm{z}$ innymi kulturami, tworzenie nowych jakości, wzajemne inspirowanie się - wszystko to jednak bez chęci zdominowania czy zasymilowania Innego, bez dążeń do „skolonizowania” jego świadomości przez kulturę dominująca na danym obszarze. Międzykulturowość rozumiana jest tutaj jako troska o własną kulturę połączona z ciekawością poznawczą nakierowaną na kultury odmienne, wyzbycie się strachu przez odmiennością i uprzedzeń wobec niej, kształtowanie pozytywnych postaw wobec inności kulturowej, rozwijanie chęci współpracy z ludźmi wywodzącymi się z różnych narodowości, kultur czy religii. Tadeusz Lewowicki, pisząc o różnicy pomiędzy edukacją wielokulturową a międzykulturową, stwierdza: „A zatem zamiast głównie «obok» ludzie (i ich kultury) powinni być i działać

2 T. Lewowicki, O podstawowych warunkach pomyślnej pracy nauczycieli w sytuacji wielokulturowości, w: T. Lewowicki, Praca nauczyciela w warunkach wielokulturowości - studia i doświadczenia z pogranicza polsko-czeskiego, red. E. Ogrodzka-Mazur, A. Szczurek-Boruta, Torun 2008, s. 21.

3 J. Nikitorowicz, Projektowanie edukacji międzykulturowej w perspektywie demokracji i integracji europejskiej, w: Edukacja międzykulturowa w wymiarze instytucjonalnym, red. J. Nikitorowicz, M. Sobecki, Białystok 1999, s. 25. 
«razem», wspólnie, dla dobra uczestniczących jednostek, społeczności i ich kultur"4.

Wśród głównych obszarów związanych z realizacją zadań edukacji międzykulturowej Jerzy Nikitorowicz wymienia:

- kształtowanie przekonania o równorzędności wszystkich kultur i przysposabianie jednostki, bez względu na jej zaplecze etniczne i kulturowe, do pokojowego życia w społeczeństwie o heterogenicznym i pluralistycznym charakterze;

- uwrażliwienie na inność i Innego, na odmienne kultury i tradycje, a także kształtowanie otwartych i tolerancyjnych postaw, które umożliwiają wymianę wartości, dialog oraz negocjacje;

- wdrażanie do dostrzegania inności jako okazji do rozwoju, jako zjawiska wzbogacającego, ciekawego, inspirującego, a nie zagrożenia;

- uświadomienie własnej tożsamości kulturowej, co ma zwiększać w rezultacie poczucie własnej wartości, bezpieczeństwa i samoakceptacji;

- kształtowanie umiejętności rozwiązywania problemów związanych z uprzedzeniami i negatywnymi stereotypami, funkcjonującymi w danej społeczności ${ }^{5}$.

Główny ciężar realizacji omówionych wyżej zadań edukacyjnych spoczywa na nauczycielach, wobec których kierowane są konkretne wymagania związane z propagowaniem określonej wiedzy, postaw, zachowań i wartości ${ }^{6}$. Żeby jednak pedagodzy mogli te zadania właściwie wypełniać, muszą przede wszystkim sami dogłębnie sobie tę wiedzę, postawy, zachowania i wartości przyswoić, aby w sposób autentyczny i przekonujący rozwijać w uczniach kompetencje międzykulturowe. Jeśli nauczyciele i wychowawcy nie będą przejawiali tolerancji, zrozumienia i otwartości wobec osób wywodzących się

4 T. Lewowicki, O podstawowych warunkach pomyślnej pracy nauczycieli w sytuacji wielokulturowości, dz. cyt., s. 21.

5 J. Nikitorowicz, Edukacja międzykulturowa wobec dylematów ksztaltowania tożsamości w spoteczeństwach wielokulturowych, w: Edukacja wobec tadu globalnego, red. T. Lewowicki, J. Nikitorowicz, T. Pilch, S. Tomiuk, Warszawa 2002, s. 42.

6 E. Ogrodzka-Mazur, „Nowy profesjonalizm” nauczyciela w kontekście przygotowania do edukacji międzykulturowej, w: Praca nauczyciela w warunkach wielokulturowości - studia i doświadczenia z pogranicza polsko-czeskiego, red. T. Lewowicki, E. Ogrodzka-Mazur, A. Szczurek-Boruta, dz. cyt., s. 27. 
z innych narodowości, wyznających odmienną religię czy pochodzących $\mathrm{z}$ odrębnych kręgów kulturowych lub też świadomie czy nieświadomie będą poddawali się negatywnym stereotypom dotyczących takich osób i przekazywali je uczniom, to wówczas edukacja międzykulturowa będzie skazana na porażkę. Aby faktycznie udało się urzeczywistnić niełatwe przecież z wielu powodów do wdrożenia cele związane $\mathrm{z}$ tym typem kształcenia i wychowania, edukacja międzykulturowa nie może być tylko kolejną szkolną ścieżką edukacyjną, „modną ideologią, zbiorem szlachetnych apeli”, czymś mało przekonującym i powierzchownym ${ }^{7}$. Dlatego też tak istotne jest odpowiednie przygotowanie nauczycieli, którym powierzy się realizację wychowania międzykulturowego. To jeden z kluczowych czynników, który składa się na szkołę przyjazną Innemu.

\section{Rola i kompetencje nauczyciela w edukacii międzykulturowej}

Nauczyciel wychowujący do międzykulturowości musi sprostać niełatwemu i posiadającemu swoją określoną specyfikę zadaniu. Zwłaszcza jeśli naucza on w grupach składających się z osób wywodzących się z różnych środowisk społecznych oraz rzeczywistości kulturowych i religijnych. Dlatego też w ramach kompetencji międzykulturowych, obok kwestii merytorycznych, niebagatelną rolę odgrywa świadomość własnego zaplecza kulturowego. Świadomość ta składa się na szerszą samoświadomość, obejmującą własną tożsamość, cechy indywidualne, emocje, postawy, wyznawane wartości, preferencje, światopogląd, którą powinien posiadać każdy nauczyciel, jednak w wypadku pedagogów pracujących w środowisku wielokulturowym nabiera ona szczególnego znaczenia ${ }^{8}$. Jest tak dlatego, że środowisko wielokulturowe to obszar nasilonej konfrontacji odmiennych zestawów wartości, zasad, norm, punktów widzenia, sposobów interpretacji rzeczywistości. Nauczyciel powinien tutaj pełnić funkcję tłumacza inności kulturowej, osoby negocjującej pomiędzy odmiennymi

7 T. Lewowicki, O podstawowych warunkach pomyślnej pracy nauczycieli w sytuacji wielokulturowości, dz. cyt., s. 15.

8 A. Gajdzica, Dziatania nauczycieli ws środowisku wielokulturowym - zatożenia a praktyka edukacyjna, w: Edukacja międzykulturowa - dokonania, problemy, perspektywy, red. T. Lewowicki, E. Ogrodzka-Mazur, A. Szczurek-Boruta, Cieszyn - Warszawa - Torun 2011, s. 112-113. 
punktami widzenia i propagatora otwartości, ciekawości i tolerancji, a to, jak się w tej roli sprawdzi, zależy w dużej mierze od jego samoświadomości. Jak stwierdza Anna Gajdzica: „Działalność człowieka jest warunkowana tym, jak on spostrzega i rozumie samego siebie. Jest to szczególnie istotne w sytuacji nauczycieli, którzy są w dużej mierze odpowiedzialni za kształtowanie postaw, budowanie otwartości dla Innych - osób reprezentujących odmienne wzory kulturowe, normy społeczne" ${ }^{\prime}$.

Owa samoświadomość jest powiązana z tzw. racjonalnością emancypacyjną zaliczaną do profesjonalnej kompetencji nauczyciela w ramach koncepcji „nowego profesjonalizmu” Juliana Elliota, skoncentrowanej na refleksyjnym podejściu nauczycieli do własnej prakty$\mathrm{ki}^{10}$. Ogrodzka-Mazur, charakteryzując racjonalność emancypacyjną, stwierdza, że wiąże się ona z „ujawnianiem zdolności do aktywnego odpowiadania na warunki otoczenia, w tym również otoczenia wielokulturowego, oraz uwalniania się od przesądów i stereotypów przez świadome oddziaływanie na przekształcanie siebie i innych w akcie wzajemnego uczenia się kulturowego, jak również ponoszeniem konsekwencji własnej aktywności"11. Aby takie podejście było możliwe, nauczyciel musi szanować zasadę dwupodmiotowości interakcji pedagogicznej oraz być zdolny do „świadomego odrzucenia ograniczeń, dokonywania zmiany i poszerzania własnej podmiotowości w różnych sytuacjach kulturowych"12. Tej postawie sprzyja zdolność do uzasadniania własnych poglądów, gotowość do ponoszenia odpowiedzialności za własne wybory i decyzje, a także świadome wykrywanie i odrzucanie stereotypów oraz zastępowanie ich nowymi jakościowo stanami poznawczymi i bazującymi na nich działaniami ${ }^{13}$.

Do poważniejszych przeszkód stojących na drodze efektywnego nauczania w ramach edukacji międzykulturowej należą negatywne stereotypy, czy w ogóle stereotypy zakodowane w nauczycielskiej świadomości, które często bywają nieuświadomione. Stereotypy są

9 Tamże, s. 114.

10 E. Ogrodzka-Mazur, „Nowy profesjonalizm” nauczyciela w kontekście przygotowania do edukacji międzykulturowej, dz. cyt., s. 28,33.

11 Tamże, s. 33.

12 Tamże.

13 Tamże, s. 33-34. 
rodzajem postaw, a postawy - co bardzo istotne w kontekście omawianej tu problematyki - przekładają się na zachowania ${ }^{14}$. Stefan Nowak stwierdza: „postawą pewnego człowieka wobec pewnego przedmiotu postaw jest ogół jego względnie trwałych dyspozycji do oceniania tego przedmiotu i emocjonalnego reagowania oraz ewentualnie towarzyszącym tym emocjonalno-oceniającym dyspozycjom względnie trwałych dyspozycji do zachowania się wobec tego przedmiotu"15. Postawy mogą być przejmowane od innych osób lub formować się w wyniku bezpośrednich doświadczeń z ich obiektem. Wyróżnia się trzy aspekty postawy: poznawczy, afektywny i behawioralny ${ }^{16}$. Czyli poza wiedzą i uczuciami w postawie mieszczą się tendencje do określonych zachowań, które przekładają się na konkretne działania (zob. rysunek 1).

Rys. 1.

Soczewkowy model wyznaczników i konsekwencii postaw

WYZNACZNIKI
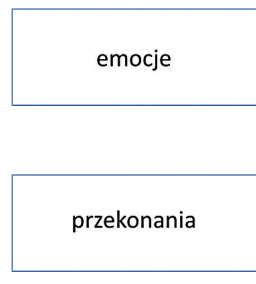

zachowanie

Źródło: B. Wojciszke, Człowiek wśród ludzi. Zarys psychologii społecznej, Warszawa 2002 , s. 181.
KONSEKWENCJE

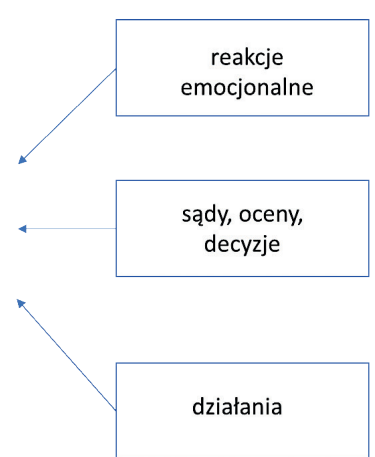

14 W. Wosińska, Psychologia życia spotecznego. Podręcznik psychologii spotecznej dla praktyków i studentów, Gdańsk 2004, s. 158.

15 S. Nowak, Pojecie postawy w teoriach $i$ stosowanych badaniach spotecznych, w: Teorie postaw, red. S. Nowak, Warszawa 1973, s. 23.

16 B. Wojciszke, Cztowiek wśród ludzi. Zarys psychologii spotecznej, Warszawa 2002, s. 181. 
Stereotyp definiuje się jako „funkcjonujący w świadomości społecznej skrótowy, uproszczony obraz rzeczywistości, potocznie zwany też «szablonem», odnoszący się także do zjawisk pozytywnych"17. Rozumie się go także jako pewną strukturę poznawczą, w ramach której mieści się wiedza, przekonania i oczekiwania osoby na temat niektórych grup społecznych ${ }^{18}$. Wiedza ta dotyczy takich aspektów, jak: cechy fizyczne, postawy, role, zachowania i preferencje uznawane za charakterystyczne dla pewnej określonej grupy, a także oczekiwania dotyczące przyszłych działań jej członków i konsekwencji tych działań ${ }^{19}$.

Stereotypy można rozpatrywać $z$ perspektywy indywidualnej oraz kulturowej. Jak stwierdza Barbara Grabowska: „[...] perspektywa kulturowa zakłada, że społeczeństwo stanowi podstawę przechowywanej wiedzy. Stereotypy natomiast stanowią integralną część struktur społecznych, wspólną dla członków danej kultury. W tym ujęciu stereotypy stanowią jeden $z$ aspektów wiedzy zbiorowej członków danego społeczeństwa, obejmującej także zwyczaje, mity, idee, systemy religijne oraz wiedzę naukową. W modelu kulturowym nabywanie, przekazywanie i zmiana stereotypów następuje poprzez źródła pośrednie, do których możemy zaliczyć informacje uzyskane od rodziców, rówieśników, nauczycieli, przywódców politycznych i religijnych, a także czerpane $z$ mass mediów [...]"20. Z perspektywy edukacji międzykulturowej szczególnie istotne jest właśnie kulturowe ujęcie stereotypów. To na ich przeobrażaniu powinien skupić się wychowawca, najlepiej poprzez tworzenie sytuacji edukacyjnych, w których uczniowie mają możliwość bezpośredniego kontaktu z Innym i innością kulturową.

Uproszczone, a przez to deformujące rzeczywistość schematy poznawcze, poprzez które postrzega się świat i innych ludzi, mogą zostać przejęte przez uczniów i przełożyć się na ich nieprzychylne

17 B. Karolczak-Biernacka, Stereotyp, w: Encyklopedia psychologii, Warszawa 1998, s. 902.

18 B. Grabowska, Inny - obcy - ...taki sam. Postawy studiujacych nauczycieli wobec Czechórw, w: Praca nauczyciela w warunkach wielokulturowości - studia $i$ doświadczenia z pogranicza polsko-czeskiego, red. T. Lewowicki, E. Ogrodzka-Mazur, A. Szczurek-Boruta, dz. cyt., s. 189.

19 Tamże.

20 Tamże, s. 189-190. 
nastawienie wobec odmienności kulturowej, etnicznej czy religijnej. Dlatego tak istotne jest pomaganie nauczycielom $\mathrm{w}$ wydobywaniu na światło dzienne żywionych przez nich i kulturę, do której przynależą, stereotypów i postaw wobec odmienności. Dodatkowo pomocne byłoby zachęcanie ich do wyrabiania większej samoświadomości w obszarach kluczowych dla kompetencji międzykulturowych, czyli w kwestii światopoglądu, wartości, postaw wobec odmienności kulturowej. Przedmiotem własnej refleksji powinny dla pedagoga stać się potoczne systemy wyjaśniania, jako że to one warunkują działania zarówno uczniów, jak i nauczycieli. To właśnie owe systemy powinny ulegać przeobrażeniu w wyniku uczenia się międzykulturowego, gdyż edukacja międzykulturowa nie może sprowadzać się wyłącznie do przekazu lub nabywania wiedzy o innych, ale musi wywoływać głębsze zmiany w postawach i nastawieniu do osób z odmiennych kręgów kulturowych i samych ich kultur ${ }^{21}$.

W świetle przedstawionych wyżej celów edukacji międzykulturowej i kompetencji, jakimi powinni wykazywać się nauczyciele międzykulturowości, należy zadać pytanie o rzeczywiste przygotowanie pedagogów do realizacji owych zadań. Badania przeprowadzone przez Ewę Ogrodzką-Mazur wśród nauczycieli pracujących na pograniczu polsko-czeskim pokazują, że wiele jest jeszcze w tej kwestii do zrobienia ${ }^{22}$. Realizacja treści międzykulturowych na zajęciach pozostawiała wiele do życzenia. Cechowała ją okazjonalność, powierzchowność, brak odwołania do szerszego kontekstu wydarzeń współczesnych, pomijanie kwestii trudnych i „kłopotliwych”, brak kreatywności w prezentacji treści i bazowanie na przekazywaniu gotowych, podręcznikowych materiałów, rzadkie odwoływanie się do doświadczenia uczniów, ich wiedzy i poglądów, dyrektywne sterowanie dyskusją i zachowaniem uczniów, duży stopień kontroli aktywności uczniów ${ }^{23}$.

Projektowane w ten sposób przez badanych nauczycieli kształcenie międzykulturowe silnie ogranicza uczniowską samodzielność, deprecjonuje i marginalizuje posiadaną przez nich wiedzę,

21 E. Ogrodzka-Mazur, „Nowy profesjonalizm” nauczyciela w kontekście przygotowania do edukacji międzykulturowej, dz. cyt., s. 28.

22 Tamże, s. 30-36.

23 Tamże, s. 30. 
doświadczenia i kompetencje, sugerując małą wartość edukacyjną tychże, a także prezentuje wiedzę szkolną jako jedynie słuszną i obiektywną ${ }^{24}$. Mamy więc tutaj do czynienia $z$ autorytarnym modelem interakcji pomiędzy nauczycielem a uczniem, skoncentrowaniem się w nauczaniu przede wszystkim na sferze intelektualnej i przekazie określonej porcji wiedzy oraz „nastawieniem na typowy, szkolny przekaz kultury, skoncentrowany na prezentowaniu uczniom tych wybranych elementów dziedzictwa kulturowego, które są uznane za jedyną prawomocną wersję opisu, wyjaśniania i interpretacji rzeczywistości przeznaczonej do zarejestrowania i utrwalenia”25.

Dodatkowo badania pokazały, że wiedza nauczycieli z zakresu międzykulturowości nie pozwala na tworzenie środowiska wspierającego uczenie się międzykulturowe ${ }^{26}$. Ich edukacyjna działalność w nikłym stopniu uwzględniała aktywność pozwalającą na doświadczanie odmiennej rzeczywistości kulturowej poprzez stwarzanie możliwości bezpośredniego kontaktu z odmiennością etniczną czy wyznaniową oraz jej przedstawicielami. Brakowało starań i umiejętności mających na celu rozbudzanie u uczniów potrzeby poznawania innych kultur oraz ciekawszych rozwiązań metodycznych z tego zakresu. Lepiej pod tym względem wypadli nauczyciele wychowania przedszkolnego i klas I-III. Niezbyt zachęcająco wypadła także samoocena nauczycieli dotycząca ich przygotowania do realizacji edukacji międzykulturowej. Ogrodzka-Mazur wyróżniła tu trzy grupy. Pierwsza, najmniej liczna grupa nauczycieli (14,6\%) deklarowała bardzo dobre przygotowanie do prowadzenia zajęć z edukacji międzykulturowej, zainteresowanie tą tematyką, wiedzę z tego zakresu oraz bardzo dobry warsztat pracy. Byli to nauczyciele z przedszkoli i szkół podstawowych z pogranicza polsko-czeskiego. Druga, najliczniejsza grupa $(46,8)$ deklarowała fragmentaryczną wiedzę o międzykulturowości, słabą ocenę własnego warsztatu pracy i nikłe zainteresowanie problemem wielokulturowości i zróżnicowania kulturowego. Do tej grupy należeli nauczyciele z gimnazjów i szkół ogólnokształcących. Grupę trzecią $(38,6 \%)$ tworzyli nauczyciele pracujący głównie w technikach lub szkołach zawodowych. Przejawiali oni obojętny lub niechętny

\footnotetext{
24 Tamże, s. 30-31.

25 Tamże, s. 31, 33.

26 Tamże, s. 34.
} 
stosunek do międzykulturowości, brak wiedzy o niej lub nikły poziom takiej wiedzy i w końcu bardzo słabe przygotowanie metodyczne w tym zakresie.

\section{Pedagogika dialogu i filozofıa dialogu a kompetencje między- kulturowe nauczycieli i tworzenie szkoły przyjaznej Innemu}

Wobec takich diagnoz oraz rozumienia funkcji i kompetencji nauczyciela $\mathrm{w}$ edukacji międzykulturowej powstaje pytanie o to, co sprzyjałoby nabywaniu przez nauczycieli opisanych powyżej zdolności krytycznych oraz samoświadomości. $Z$ tym pytaniem powiązana jest też kwestia ogólniejsza - jakie działania pedagogiczne sprzyjałyby tworzeniu szkoły, w której możliwe byłoby realizowanie z sukcesem specyficznych dla edukacji międzynarodowej celów. $Z$ pomocą może tu przyjść inspirowana filozofią hermeneutyczną, a zwłaszcza hermeneutyką Hansa-Georga Gadamera, propozycja Joanny Rutkowiak sytuująca się w ramach pedagogiki dialogu. Badaczka postuluje ustanowienie dialogu „przewodnią ideą przepajającą całość wychowania”27. Pisze ona o „zasadzie dialogowości”, którą rozumie jako „otwarty, procesualny, krytyczny, wewnętrznie skontrastowany sposób myślenia"28.

Jednym z przejawów tego sposobu myślenia jest myślenie globalizujące, poszerzające horyzonty, umożliwiające stawianie pytań pozbawionych łatwych i jednoznacznych odpowiedzi. Globalne myślenie i zapytywanie osadza fragmentaryczną zazwyczaj wiedzę szkolną w szerszych kontekstach umożliwiających lepsze rozumienie siebie i świata poprzez uchwycenie całościowych sensów. Dodatkowo pozwala ono na problematyzację tej wiedzy, wyjście w dydaktyce poza wyłączne koncentrowanie się na kwestii skuteczności przekazywania określonych. Pozwala też na poszerzanie horyzontów, krytyczne spoglądanie na prezentowane informacje, odsłanianie ukrytych założeń obecnych w naszym myśleniu i włączenie do dyskusji większej liczby punktów widzenia, większej liczby różnych głosów, co sprawia, że dyskusja, której patronuje myślenie globalne staje się bardziej otwarta,

27 J. Rutkowiak, O dialogu edukacyjnym. Rusztowanie kategorialne, w: Pytanie. Dialog. Wychowanie, red.J. Rutkowiak, Warszawa 1992, s. 51.

28 Tamże. 
wolna, twórcza i uwzględniająca więcej możliwych rozwiązań danego problemu. Rutkowiak zachęca do krytycznego przyglądania się wraz z uczniami prezentowanej na lekcjach wiedzy poprzez włączenie w większym niż ma to miejsce obecnie stopniu pytań globalizujących, inspirujących poznawczo, twórczych, skłaniających uczniów do umysłowego wysiłku większego niż tylko odtwarzanie informacji lub schematycznych procedur poznawczych ${ }^{29}$.

Takie zalecenia i propozycje zdają się doskonale odpowiadać na potrzeby edukacji międzykulturowej, która w sposób konieczny wiąże się z poszerzaniem perspektyw poznawczych uczniów o inne punkty widzenia wywiedzione $\mathrm{z}$ różnych kultur. Zetknięcie się z odmiennymi sposobami interpretowania tych samych faktów, innymi sposobami podchodzenia do tych samych zagadnień czy też różniącymi się od naszej interpretacjami rzeczywistości odsłania problematyczność twierdzeń roszczących sobie prawo do wyłączności i może otworzyć jednostkę na perspektywę dialogiczną, która nie chce już narzucać wszystkim jakichś prawd ostatecznych i niepodważalnych, lecz nastawiona jest na „ciągłe konstytuowanie i przezwyciężanie sensów”30. Tylko takie podejście, oparte na włączaniu do dyskusji wciąż nowych kulturowych perspektyw, na dopuszczanie do głosu innych z ich obrazem świata i specyficznymi poglądami, gwarantuje pokojowe współistnienie różnych kultur, nieoparte na poznawczej dominacji (która pociąga za sobą inne rodzaje dominacji, włącznie z polityczną i ekonomiczną), lecz na negocjacji i wspólnym budowaniu i ustalaniu sensów. Perspektywa dialogiczna przepajająca szkolną rzeczywistość otwiera przestrzeń dla tolerancji i szacunku do odmienności, daje uczniom wywodzącym się z mniejszości narodowych, etnicznych czy religijnych poczucie uczestnictwa we wspólnocie szkolnej i - co za tym idzie - w społeczeństwie, a także poczucie bycia akceptowanym takim, jakim się jest. Daje możliwość wnoszenia własnego punktu widzenia do dyskusji, podnosi poczucie własnej wartości i wartości własnej tożsamości kulturowej jako równorzędnej wobec tej dominującej.

Dialog w szerokim rozumieniu, o jakim pisze Rutkowiak, nie daje w rezultacie jakiegoś gotowego i ostatecznego sensu, który zamykałby

29 Tamże, s. 49.

$30 \quad$ Tamże, s. 41. 
dyskusję. Formą dialogu, którą badaczka uważa za szczególnie trafną jako wzorzec dialogu edukacyjnego jest rozmowa ${ }^{31}$. Różni się ona od typowej dyskusji „szkolnej”, która jest ograniczającą samodzielność dyskutantów dyskusją kierowaną ${ }^{32}$, i od dyskusji „właściwej”, która jest nastawiona na rozwiązanie określonego problemu ${ }^{33}$, bardziej otwartą formułą i brakiem zwieńczenia w postaci wypracowanego rozwiązania danej kwestii. Rozmowa nie kończy się definitywnym, zamykającym wnioskiem, lecz jest otwarta na ciągłe przeformułowania w obrębie założeń, argumentów, wniosków. Jest mniej zdyscyplinowana od dyskusji „właściwej”. Nie występuje tutaj też autorytatywne, zewnętrzne kierownictwo. Temat rozmowy dobierany jest ze względu na wewnętrzne potrzeby jej uczestników, którzy są żywotnie zainteresowani daną kwestią i szukają pomocy i opinii innych, chcąc naświetlić i rozjaśnić jakiś złożony problem. Rozmówcy kierują się zarówno krytycyzmem, jak i odpowiedzialnością za własne słowa. Takie jednak - z pozoru swobodne - rozmowy dają poważne rezultaty, a jej uczestnicy wnoszą do niej istotny wkład poznawczy. Poprzez rozmowę jej uczestnicy mogą zapoznać się z różnymi punktami widzenia na omawianą kwestię. Może ona w danej chwili zostać zawieszona, ale może być kontynuowana później, kiedy rozmówcy dojdą do nowych wniosków lub będą mieli nowe pomysły na rozwiązanie interesującego ich problemu. Ten brak zamknięcia, otwartość procesu poznawczego, jakim jest rozmowa, odróżnia ją od dyskusji.

Zaangażowanie się w rozmowę daje szansę spotkania się z tym, co odmienne, czymś, co przekracza nasz dotychczasowy poznawczy horyzont i daje do myślenia. $\mathrm{W}$ rozważaniach nad przekraczaniem horyzontów poznawczych Rutkowiak odwołuje się do myśli Gadamera i w jej świetle rozwija swoją refleksję nad rozmową jako formą dialogu różną od dyskusji „szkolnej” i dyskusji „właściwej”34. Zauważa, że rozmowa umożliwia poznawcze przeobrażenie jednostki. Spotkanie z drugim człowiekiem jest jednocześnie spotkaniem z odmiennym od naszego obrazem świata, a tym samym możliwością otwarcia się na to, co inne. To otwarcie $z$ kolei i przyjęcie tego, co

Tamże, s. 37.

2 Tamże, s. 34.

33 Tamże, s. 36.

34 Tamże, s. 41-42. 
nieznane, staje się jednocześnie szansą na jednostkową przemianę. Rozmowa różni się od prostej wymiany informacji, odbiega też od zdyscyplinowanej formy dyskusji „właściwej”. Wykracza poza negocjowanie i „stwarza szanse narodzin odmiennego punktu widzenia, poszerzania bądź przebudowywania siebie, możliwego dzięki inności innych" ${ }^{35}$. Nie idzie w niej o ustalenie jakiegoś stanu obiektywnego, ale raczej o ciągłe przekraczanie wcześniejszych ustaleń i budowanie coraz to nowszych sensów.

Zasadniczy cel edukacji międzykulturowej lub co najmniej jeden z jego najistotniejszych komponentów, podobnie jak to ma miejsce w wypadku hermeneutycznie rozumianej rozmowy, można określić jako poznawcze przeobrażenie (albo ukształtowanie) jednostki. Owo przeobrażenie ma się dokonać w zakresie postrzegania Innego poprzez uświadomienie sobie i modyfikację uproszczonych i negatywnych schematów poznawczych odnoszących się do Innego, a także zmianę warunkujących działanie potocznych systemów wyjaśniania na bardziej otwarte i sprzyjające wymianie i komunikacji międzykulturowej oraz poprzez poznawcze otwarcie na inność i dostrzeżenie jej wzbogacającego i poszerzającego horyzonty potencjału. Edukacja międzykulturowa, podobnie jak rozmowa, ma otwierać na odmienne perspektywy, poglądy, światopoglądy, wartości, które mogą zostać włączone w horyzont poznawczy jednostki, tym samym dokonując jego przeobrażenia i zmieniając jednostkę, a co za tym idzie jej postawy i zachowania. Ta transformacja jest możliwa dzięki „inności innego", dzięki różnicy, która staje się tutaj wartością umożliwiającą przeobrażenie jednostki, wykroczenie poza siebie i swój świat ku Innemu, włączenie go do nieustającej rozmowy, która ciągle dodaje nowe punkty widzenia i przebudowuje sensy. Dlatego też sądzimy, że wdrożenie rozmowy jako formy dialogu edukacyjnego, który przyświecałby edukacji międzykulturowej, mogłoby pomóc w realizacji celów tego projektu pedagogicznego nakierowanego na zwiększenie współpracy i porozumienia pomiędzy odmiennymi kulturami.

Rozmowy nie należy jednak rozumieć tylko jako pewnej techniki, jako metody dydaktycznej nastawionej na konkretne i mierzalne rezultaty edukacyjne. Rutkowiak, za Gadamerem, pojmuje dialogiczność i rozmowę bardzo szeroko: jako „warunek możliwości

35 Tamże, s. 42. 
rozumienia”, w którym „idzie o ciągłe konstytuowanie i przezwyciężanie sensów, dziejące się przez wymianę myśli, będące aktywnością ustawiczną, ludzkim sposobem bycia; rozumienie nie oznacza tutaj więc odtwarzania ustalonych już znaczeń - jak się je zazwyczaj interpretuje w pedagogice" ${ }^{36}$. Dialog i dialogowość w tej koncepcji wiążą się więc z poszerzonym pojmowaniem samego rozumienia, które przestaje być związane wylącznie $z$ domeną poznawczą i staje się sposobem bycia.

Przełożenie tak rozumianej rozmowy na edukację polegałoby m.in. na spojrzeniu na nauczycieli i uczniów nie jako na dwie różne i przeciwstawne strony wymiany myśli, ale na osoby znajdujące się w tej samej sytuacji poznawczej, tzn. ludzi „uczących się zarazem siebie i świata" ${ }^{37}$. Bycie nauczycielem i uczniem staje się tutaj kwestią drugorzędną, a pedagog, jak i jego wychowanek traktowani są przede wszystkim jako ludzie doświadczający, pragnący zrozumieć siebie i otaczający świat poprzez rozmowę. Takie podejście wynika z inspiracji filozofią hermeneutyczną, gdzie krytyce podlega podejście opierające się na przeciwstawianiu podmiotu i przedmiotu, podejście, które przenika również myślenie pedagogiczne ${ }^{38}$. U podstawy takiego opozycyjnego myślenia leży przekonanie o poznawczej dominacji rozumiejącego podmiotu, która umożliwia mu panowanie nad określonym przedmiotem i kształtowanie go według własnych wyobrażeń. Jednak takie podejście sprawia, że przekonany o własnej wiedzy podmiot nie jest skory do dialogowania i może lekceważyć odmienne stanowiska, głosy i punkty widzenia ${ }^{39}$. Skutkami tej mocno zakorzenionej w pedagogice zasady jest obecność w jej refleksji wielu silnych przeciwstawień, które utrudniają dialog jako swobodną i otwartą wymianę myśli pomiędzy różnymi podmiotami zaangażowanymi w edukację i wychowanie ${ }^{40}$. Jednym $\mathrm{z}$ tych przeciwstawień jest właśnie opozycja pomiędzy nauczycielami a uczniami, którą należy, zdaniem Rutkowiak, przezwyciężyć w duchu rozmowy.

\footnotetext{
36 Tamże, s. 41.

37 Tamże, s. 42.

38 Tamże, s. 41-42.

39 Tamże, s. 44.

40 Tamże, s. 43-44.
} 
Z dialogowością jako zasadą niezwykle istotną w relacjach międzyludzkich spotykamy się również w filozofii dialogu, której najwybitniejszymi reprezentantami są tacy myśliciele, jak: Martin Buber, Franz Rosenzweig czy Emmanuel Lévinas. Filozofię dialogu inspirującą się tradycją judeochrześcijańską wskazuje Rutkowiak ${ }^{41}$ jako drugie ważne źródło myślenia dialogicznego w kulturze europejskiej po dziedzictwie antycznej greckiej filozofii i dramaturgii. Z filozofii dialogu, podobnie jak z „zasady dialogowości” omawianej badaczki, mogą wynikać inspirujące implikacje dla pedagogiki w ogólności oraz edukacji międzykulturowej.

Główne zainteresowania myślicieli należących do tego nurtu filozoficznego oscylują wokół człowieka i relacji międzyludzkich, a tym samym są bliskie problematyce nauk o wychowaniu. Przy tym, z jednej strony, sami przedstawiciele filozofii dialogu wykazują duże zainteresowanie kwestiami wychowania, a $\mathrm{z}$ drugiej strony ich koncepcje znajdują uznanie wśród pedagogów i stają się inspiracją dla koncepcji pedagogicznych ${ }^{42}$. Na dowód centralnego miejsca problematyki antropologicznej w filozofii dialogu można przywołać znaną Buberowską „zasadę dialogiczną”, która głosi, że podstawowym faktem decydującym o istocie ludzkiej egzystencji jest „człowiek z człowiekiem”, a stawanie się przez Ja osobą w sposób konieczny odbywa się poprzez spotkanie z $\mathrm{Ty}^{43}$. Takie żywe, bezpośrednie spotkanie stanowi

${ }^{41}$ Tamże, s. 23.

42 O zainteresowaniu filozofów dialogu kwestiami kształcenia i wychowania świadczą m.in. ich prace poświęcone wyłącznie tym zagadnieniom. Można wśród nich wymienić: M. Buber, Wychowanie, w: Źródta do dziejów wychowania i myśli pedagogicznej, t. 3 ks. 2: Myśl pedagogiczna w XX stuleciu, wybór i oprac. S. Wołoszyn, Kielce 1998; tenże, Ksztatcenie charakteru, „Znak”1968, nr 7-8; E. Lévinas, O hebrajski humanizm, Rozważania o edukacji żydowskiej, Antyhumanizm a edukacja w: tenże, Trudna wolność. Eseje o judaizmie, przeł. A. Kuryś, Gdynia 1991; J. Tischner, Z problematyki nauczania, „Znak” 1968, nr 7-8; tenże, Zadania wychowawcze, „Tygodnik Powszechny” 1972, nr 9; T. Gadacz, Wychowanie jako spotkanie osób, „Znak” 1991, nr 9; tenże, Wychowanie do wolności, „Znak” 1993, nr 9. O zainteresowaniu pedagogów kwestią dialogu oraz filozofii dialogu świadczy m.in. seria pt. Pedagogika dialogu wydawana przez Wydawnictwo Akademii Pedagogiki Specjalnej oraz takie pozycje, jak: J. Rutkowiak, Pytanie, dialog, wychowanie, Warszawa 1992; J. Gara, Pedagogiczne implikacje filozofii dialogu, Kraków 2008; M. Jagiełło, Spotkania, które zmieniaja. O spotkaniu jako kategorii pedagogicznej i wydarzeniu wychowujacym na drodze życia, Kraków 2012.

43 M. Buber, Problem człowieka, przeł. J. Doktór, Warszawa 1993, s. 91. 
w filozofii Bubera wzorzec dla międzyludzkich interakcji, a jego antytezą jest postrzeganie człowieka jako podmiotu poznającego zawłaszczającego byt w aktach poznawczych. Prawdziwe spotkanie $\mathrm{z}$ drugą osobą musi wiązać się z porzuceniem postawy zdystansowanego obserwatora i zanurzeniem się w bezpośredniości wydarzenia, w którym osoby otwierają się na siebie.

Wychowawcze przesłanie filozofii dialogu, zwanej także dialogiką, głosi, że „to [...], kim się jest, tak naprawdę decyduje o tym, co można wnieść w życie innego człowieka, wychowanka; czego nauczyć, do czego zainspirować, rozbudzając życiowe zorientowania"44. Tym samym dialogika i inspirowane nią nurty pedagogiki dialogu w zakresie wychowawczo-edukacyjnym głoszą kluczową rolę nauczyciela i jego relacji z wychowankiem, wyznaczając drugoplanową rolę, a nawet wskazując niebezpieczeństwa i słabe punkty narzucanych odgórnie nakazów i dyrektyw, masowo stosowanych procedur edukacyjnych i wychowawczych czy w końcu różnych form instytucjonalnego przymusu.

W optyce dialogicznej, aby wychowanie mogło być skuteczne i oddziaływać na uczniów w pogłębiony sposób, musi ono mieć kształt partnerskiej współpracy i „osobowo inspirującego sposobu bycia" ${ }^{45}$. Nauczyciel powinien umieć dostrzec i uszanować uczniowską indywidualność, inność i odrębność wewnętrznego świata każdego ze swoich wychowanków. Niedopuszczalne jest, aby opierał on swoją wychowawczą i edukacyjną aktywność na chęci panowania, zawłaszczenia i dominacji.

Kolejnym wartym wspomnienia $\mathrm{w}$ ramach prezentowanych w tym artykule zagadnień elementem dialogiki jest, podkreślana w filozofii wychowania Bubera, umiejętność wczucia się w sytuację innego i spojrzenia na sprawy z jego punktu widzenia. Wrażliwość na komunikaty wysyłane przez drugą osobę oraz zdolność do empatycznego postawienia się w jego sytuacji powodują, że wychowawca może odrzucić postawę zdystansowanego obserwatora i przejąć się losem wychowanka. Kluczowe w filozofii dialogu dla zrozumienia zarówno innych, jak i siebie jest bezpośrednie spotkanie z drugim człowiekiem. Ten drugi w spotkaniu może odsłonić przed nami swój własny

44 J. Gara, Pedagogiczne implikacje filozofii dialogu, Kraków 2008, s. 47.

45 Tamże. 
świat i wartości, jakie reprezentuje, pod warunkiem, że poświęcimy mu swój czas i uwagę.

Opisane powyżej dyrektywy i powinności, wywiedzione z filozofii dialogu, są istotne jako ogólne zalecenia dla nauczycieli, ale nabierają szczególnego wyrazu w ramach edukacji międzykulturowej. Nauczyciel pracujący w środowisku wielokulturowym, najczęściej będąc reprezentantem kultury dominującej, powinien wyrzec się chęci kulturowego panowania, zawłaszczania i narzucania własnych norm i sposobów interpretowania świata jako jedynie właściwych uczniom pochodzącym z odmiennych kręgów kulturowych. Takie tendencje mogą występować zarówno na poziomie świadomym, jak i nieświadomym, np. jako nieuświadomione negatywne stereotypy lub kulturowe schematy poznawcze uznawane niesłusznie za uniwersalne. Tutaj z pomocą przychodzi rozmowa w rozumieniu przedstawionym przez Rutkowiak, która oferuje poznawczy sposób na odsłanianie ukrytych założeń i schematów i ich zmianę poprzez dialog z Innym, $\mathrm{z}$ jego odrębnym punktem widzenia.

Większość wymienionych wyżej pochodzących z dialogiki powinności pedagogicznych można umieścić pod hasłem „zwiększonej wrażliwości na Innego". W ramach edukacji międzykulturowej prowadzonej w środowisku wielokulturowym brak owej wrażliwości, czy też niektórych jej aspektów, może mieć o wiele poważniejsze konsekwencje niż w wypadku środowiska monokulturowego. Dzieje się tak dlatego, że praca w środowisku wielokulturowym często wiąże się $\mathrm{z}$ ułatwianiem funkcjonowania w nowym lub obcym kulturowo środowisku osobom, które przybyły $\mathrm{z}$ niejednokrotnie radykalnie odmiennych kulturowych światów i dodatkowo mogą mieć za sobą traumatyczne przeżycia, tak jak to ma miejsce w wypadku uchodźców. Nauczyciel musi zatem brać pod uwagę zróżnicowaną sytuację uczniów w prowadzonej przez siebie grupie, jeśli nie chce, aby jego działania zakończyły się niepowodzeniem. Owo zróżnicowanie jest rezultatem nakładania się wielu czynników. Wśród nich można wymienić status społeczny i ekonomiczny rodziny ucznia, rodzaj doświadczeń wyniesionych z kraju ojczystego, kulturę kraju pochodzenia i wyznawaną religię. To właśnie one w dużym stopniu będą decydowały o przebiegu edukacji i integracji danego ucznia. 


\section{Zakończenie}

Nauczyciel musi „wyjšć ku” uczniowi, nauczyć się go rozumieć na głębszym poziomie, dostrzec specyfikę zarówno jego kulturowego zaplecza, jak i indywidualności, cech charakteru, predyspozycji i potencjału. Musi w większym stopniu dbać o kwestie komunikacyjne, gdyż na przeszkodzie mogą stać kwestie językowe czy też pewne behawioralne i niewerbalne kody komunikacyjne wyniesione przez ucznia z innej kultury. Ogólnie rzecz biorąc, w sytuacji pracy w środowisku wielokulturowym otwartość na inność i Innego, kompetencje komunikacyjne, chęć wychodzenia naprzeciwko Innego, poziom wyczulenia na sygnały od niego płynące czy w końcu poziom świadomości własnych uwikłań kulturowych i poznawczych musi być wyższy niż w wypadku pedagogów pracujących w środowisku monokulturowym.

To postawa pedagoga i stopień, w jakim przyswoił on sobie cechy kluczowe dla kompetencji międzykulturowej, mają zasadnicze znaczenie, czy będzie on w stanie skutecznie przekazać istotne dla wychowania międzykulturowego zachowania, wzorce czy sposób myślenia. Kluczowe dla jego postawy wydają się opisane w artykule cechy, dyspozycje i kompetencje, których nabywanie ułatwia zastosowanie dialogicznej koncepcji edukacji Rutkowiak oraz dyrektyw wywiedzionych $\mathrm{z}$ filozofii dialogu i czerpiących $\mathrm{z}$ tego nurtu projektów pedagogicznych.

\section{Bibliografia}

Buber M., Ksztatcenie charakteru, „Znak” 1968, nr 7-8, s. 915-926.

Buber M., Problem cztowieka, przeł. J. Doktór, Wydawnictwo Naukowe PWN, Warszawa 1993.

Buber M., Wychowanie, w: Źródta do dziejów wychowania i myśli pedagogicznej, t. 3, ks. 2: Myśl pedagogiczna w XX stuleciu, wybór i oprac. S. Wołoszyn, Dom Wydawniczy „Strzelec”, Kielce 1998, s. 649-654.

Gadacz T., Wychowanie do wolności, „Znak” 1993, nr 9, s. 97-114.

Gadacz T., Wychowanie jako spotkanie osób, „Znak” 1991, nr 9, s. 62-68.

Gajdzica A., Dziatania nauczycieli w środowisku wielokulturowym - zatożenia a praktyka edukacyjna, w: Edukacja międzykulturowa - dokonania, problemy, perspektywy, red. T. Lewowicki, E. Ogrodzka-Mazur, A. Szczurek-Boruta, Wydawnictwo Adam Marszałek, Cieszyn - Warszawa - Toruń 2011, s. 112-150. 
Gara J., Pedagogiczne implikacje filozofi dialogu, Wydawnictwo WAM, Kraków 2008.

Grabowska B., Inny - obcy - ...taki sam. Postawy studiujacych nauczycieli wobec Czechów, w: Praca nauczyciela w warunkach wielokulturowości studia i doświadczenia z pogranicza polsko-czeskiego, red. T. Lewowicki, E. Ogrodzka-Mazur, A. Szczurek-Boruta, Wydawnictwo Adam Marszałek, Torun 2008, s. 183-201.

Jagiełło M., Spotkania, które zmieniaja. O spotkaniu jako kategorii pedagogicznej $i$ wydarzeniu wychowujacym na drodze życia, Oficyna Wydawnicza „Impuls”, Kraków 2012.

Karolczak-Biernacka B., Stereotyp, w: Encyklopedia psychologii, Wydawnictwo Fundacja Innowacja, Warszawa 1998, s. 902.

Lévinas E., O hebrajski humanizm, Rozważania o edukacji żydowskiej, Antyhumanizm a edukacja, w: E. Lévinas, Trudna wolność. Eseje o judaizmie, przeł. A. Kuryś, Atext, Gdynia 1991, s. 82-95.

Lewowicki T., O podstawowych warunkach pomyślnej pracy nauczycieli w sytuacji wielokulturowości, w: Praca nauczyciela w warunkach wielokulturowości - studia i doświadczenia z pogranicza polsko-czeskiego, red. T. Lewowicki, E. Ogrodzka-Mazur, A. Szczurek-Boruta, Wydawnictwo Adam Marszałek, Toruń 2008, s. 13-23.

Nikitorowicz J., Edukacja międzykulturowa wobec dylematów ksztattowania tożsamości w spoteczeństwach wielokulturowych, w: Edukacja wobec tadu globalnego, red. T. Lewowicki, J. Nikitorowicz, T. Pilch, S. Tomiuk, Wydawnictwo Akademickie „Żak”, Warszawa 2002, s. 33-55.

Nikitorowicz J., Projektowanie edukacji międzykulturowej w perspektywie demokracji i integracji europejskiej, w: Edukacja międzykulturowa w wymiarze instytucjonalnym, red. J. Nikitorowicz, M. Sobecki, Wydawnictwo Uniwersyteckie „Trans Humana”, Białystok 1999, s. 25-31.

Nowak S., Pojecie postawy w teoriach i stosowanych badaniach spotecznych, w: Teorie postaw, red. S Nowak, PWN, Warszawa 1973, s. 15-27.

Ogrodzka-Mazur E., „Nowy profesjonalizm” nauczyciela w kontekście przygotowania do edukacji międzykulturowej, w: Praca nauczyciela w warunkach wielokulturowości - studia $i$ doświadczenia z pogranicza polsko-czeskiego, red. T. Lewowicki, E. Ogrodzka-Mazur, A. Szczurek-Boruta, Wydawnictwo Adam Marszałek, Toruń 2008, s. 25-72.

Rutkowiak J., O dialogu edukacyjnym. Rusztowanie kategorialne, w: Pytanie. Dialog. Wychowanie, red. J. Rutkowiak, Wydawnictwo Naukowe PWN, Warszawa 1992, s. 13-52.

Tischner J., Z problematyki nauczania, „Znak” 1968, nr 7-8, s. 903-914.

Tischner J., Zadania wychowawcze, „Tygodnik Powszechny” 1972, nr 9, s. 20-22.

Urząd do Spraw Cudzoziemców, https://udsc.gov.pl/statystyki/raporty-okresowe/raport-roczny-legalizacja-pobytu/2017-2/ [dostęp: 29.08.2018]. 
Wojciszke B., Człowiek wśród ludzi. Zarys psychologii spotecznej, Wydawnictwo Naukowe „Scholar”, Warszawa 2002.

Wosińska W., Psychologia życia spotecznego. Podręcznik psychologii spotecznej dla praktyków i studentów, Gdańskie Wydawnictwo Psychologiczne, Gdańsk 2004.

\section{ADRES DO KORESPONDENCJI}

Dr Jadwiga Serkowska-Mqka

Wyższa Szkoła Menedżerska w Warszawie

Wydział Nauk Społecznych i Administracji

e-mail: jserkowskam@wp.pl 